Full Length Article

\title{
Ethyl esters obtained from pequi and macaúba oils by transesterification with homogeneous acid catalysis
}

\section{Raflem Christian Matos dos Santos ${ }^{\mathrm{a}, *}$, Paula Cristina Gurgel ${ }^{\mathrm{a}}$, Nizamara Simenremis Pereira ${ }^{\mathrm{b}}$, Rodolfo Andrade Breves ${ }^{\mathrm{c}}$, Paulo Roberto Rodrigues de Matos ${ }^{\mathrm{d}}$, Luciano Paulino Silva ${ }^{\mathrm{e}}$, Maria José Araújo Sales ${ }^{c}$, Roseany de Vasconcelos Vieira Lopes ${ }^{\mathrm{f}}$}

${ }^{a}$ Departamento de Engenharia Mecânica, Universidade de Brasília, 70910-900, Campus Darcy Ribeiro, Brasília, DF, Brazil

${ }^{\mathrm{b}}$ Instituto Federal de Brasília, Campus Gama, 72405-025 Gama, DF, Brazil

${ }^{\mathrm{c}}$ Instituto de Química, Universidade de Brasília, Campus Darcy Ribeiro, 70904-970 Brasília, DF, Brazil

${ }^{\mathrm{d}}$ Centro de Pesquisas e Análises Tecnológicas (CPT), Agência Nacional de Petróleo, Gás Natural e Biocombustíveis (ANP), 70830902 Brasília, DF, Brazil

${ }^{\mathrm{e}}$ Embrapa Recursos Genéticos e Biotecnologia, Laboratório de Nanobiotecnologia (LNANO), 70770-917 Brasília, DF, Brazil

${ }^{\mathrm{f}}$ Faculdade do Gama, Universidade de Brasília, 72405-610 Gama, DF, Brazil

\section{A R T I C L E I N F O}

\section{Keywords:}

Renewable energy

Biodiesel

Homogeneous acid catalysis

Ethyl esters

Macaúba

Pequi

\begin{abstract}
A B S T R A C T
In this work, it was investigated the presence of ethyl esters in transesterified pequi (PO) and macaúba (MO) oils. To obtain the biodiesel, an acid-catalyzed homogeneous reaction was used. Yields of 95\% for MO were obtained using an oil:ethanol ratio of 1:30 and sulfuric acid $\left(\mathrm{H}_{2} \mathrm{SO}_{4}\right)$, reaction times of $4,8,12$, and $24 \mathrm{~h}$ were used. The biodiesel samples obtained from the PO are denoted BP4, BP8, BP12, and BP24, and those from MO are denoted BM4, BM8, BM12, and BM24 according to the reaction time. The kinematic viscosity of the biodiesels was satisfactory and within the specifications stipulated by ANP. The density analysis showed that the biodiesels presented values that are within the limits stipulated by ANP and the European Union. With ${ }^{1} \mathrm{H}$ NMR measurements, the presence of ethyl esters and the conversion rates were verified. The results by oxidative stability showed that the biodiesel obtained for $24 \mathrm{~h}$ are close to the values required by the ANP. The analysis of the ester content showed that the biodiesels obtained with the longest reaction time are in accordance with ANP resolution specifications. Raman spectroscopy revealed the stretching band of the C-O-C group in the ethyl ester molecule at $870 \mathrm{~cm}^{-1}$ for all samples. Using thermogravimetry, the maximum degradation temperatures were 243 and $205^{\circ} \mathrm{C}$ for BP and BM, respectively. The characteristic absorption bands of the transesterified oils were identified by FT-IR at $743 \mathrm{~cm}^{-1}(\mathrm{C}=\mathrm{O}$ group of the ethyl esters $)$ and $800-1700 \mathrm{~cm}^{-1}(\mathrm{C}=\mathrm{O}$ of esters).
\end{abstract}

\section{Introduction}

The large-scale use of fossil fuels is environmentally damaging. The burning of petroleum derivatives is responsible for most emissions of greenhouse gases (GHG), mainly $\mathrm{CO}_{2}$ [1]. Thus, the use of fossil fuels should be reduced, and various alternative sources of energy should be used. Biodiesel is a suitable alternative energy source [2].

The National Agency for Petroleum Natural Gas and Biofuels (ANP) defines biodiesel as a fuel composed of alkyl esters of long carboxylic acids chains that is produced from the transesterification or esterification of fatty materials of vegetable or animal origin [3].

Biodiesel is considered the main substitute for petrochemical diesel because the physicochemical properties of biodiesel are similar to those of traditional fossil fuels; also, the raw materials for biodiesel are renewable and abundant. Crucially, biofuel can be used in diesel engines without the need for modification and can be used pure or mixed with diesel oil $[4,5]$.

Biodiesel is obtained via transesterification reactions, where the triglycerides present in a lipid are reacted with short chain alcohol, usually methanol or ethanol, in the presence of a catalyst, resulting in a mixture of alkyl esters of fatty acids (biodiesel) and glycerol [6,7].

Generally, the most commonly used alcohol in transesterification reactions is methanol, since it has some advantages over ethanol, such as easier separation of biodiesel and glycerol, and lower cost in most countries $[8,9]$. However, Brazil is the leading producer of ethanol from sugarcane, and therefore, ethanol is cheaper than methanol because of the large volume of production [10-12]. Allied to this, ethanol is obtained from a clean source, and so it is environmentally friendly to

\footnotetext{
* Corresponding author.

E-mail addresses: raflem.christian@gmail.com, 180058894@aluno.unb.br (R.C.M. dos Santos).
} 
reactions which ethanol is used $[13,14]$. Also, ethanol has better solubility for vegetable oils and is less toxic than methanol [15].

Some studies were considered in which ethanol was used to produce biodiesel, using different sources and heterogeneous catalysis: Turkkul et al. [13] produced ethyl esters from the lipid of two types of microalgae (Nannochloropsis oculata and Spirulina sp.) with $60 \mathrm{wt} \% \mathrm{CaO}$ on $\mathrm{Al}_{2} \mathrm{O}_{3}$ catalyst. They obtained $90-99 \%$ biodiesel yield with $24: 48$ ethanol:lipid molar ratios. Belo Pasa et al. [14] produced ethyl esters from the macauba oil with heterogeneous acid catalyst, varying the reaction temperature and the molar ratio of ethanol:oil, and it obtained biodiesel in the best condition at $130{ }^{\circ} \mathrm{C}$ with ethanol:oil molar ratio of 9 and $16 \mathrm{wt} \%$ of catalyst. Silva et al. [2] produced ethyl and methyl esters from pequi oil using an alkaline homogeneous catalyst and obtained yields of 80 and $96 \%$ for ethyl and methyl biodiesel, respectively. Loures et al. [16] also produced ethyl esters, but instead of using vegetable oil, microalgae oil was used (Chlorella minutissima) via acid catalysis in a homogeneous and heterogeneous route, and yield of $96.5 \%$ and $98 \%$ for each of them were obtained, respectively.

For the homogeneous catalysts, the alkaline route is more used than the acid. However, its use has some limitations, such as the high sensitivity only when purity reagents are used, the quantity of water, and free fatty acids (FFA) of the oil. The FFA mainly, because this type of catalysis favors saponification reactions. Thus, for oils which have a high acid value, the most suitable homogeneous catalyst is the acid $[17,18]$.

Another advantage of this route is that it is cheaper when the oil requires a reduction in the content of free fatty acids because when there is a large amount of FFA, it is necessary to perform pre-treatment. Therefore, with an acid route, the esterification step does not have to be done, and the costs are reduced [19].

Mathimani et al. [20] produced biodiesel from algae (Chlorella sp. BDUG 91771) using homogeneous and heterogeneous acid and alkaline catalysts. The highest concentration of biodiesel was obtained with a homogeneous acid catalyst, using $3.5 \%$ of sulfuric acid in $2.5 \mathrm{~h}$ of reaction at $60{ }^{\circ} \mathrm{C}$ in constant agitation, obtaining $60 \%$ conversion to methyl esters.

The most commonly used raw materials to produce biodiesel in Brazil are soybean oil and bovine tallow. In 2015, these sources represented about $95 \%$ of the total biodiesel production, and, although they are already consolidated in the market, biodiesel production can be diversified by using other crops, which, as well as helping supplydemand, may increase the value of poorly utilized, high-potential species such as macaúba and pequi, oleaginous crops of the Cerrado ecoregion $[1,5]$.

The Cerrado occupies about $22 \%$ of the Brazilian territory and has a high degree of biodiversity, possessing more than 7000 species of plants. It is considered the most diverse tropical savannah in the world [21].

Pequi (Caryocar brasiliense Camb.) fruit is produced between September and February, and it consists of a seed surrounded by an oily pulp. One of the advantages of using pequi oil for biodiesel production is the number of antioxidant substances that it possesses, which means that the fuel has greater oxidative and thermal stability [22]. Macaúba (Acrocomia aculeata (Jacq.) Lood. ex. Mart) is a coconut tree that produces fruits with oil contents of 50-60\%, having an oil productivity that can reach $4220 \mathrm{~L} \mathrm{ha}^{-1}$. From its fruit, it is possible to extract two types of oils, one from its seed and one from its pulp, which is the most used $[1,23,24]$. It is an oil that has a high value of free fatty acids, and this makes it not commonly used as food $[25,26]$. Table 1 shows some properties of the pequi (PO) and macaúba (MO) oils.

The composition of FFAs of the two oils (Table 1) shows similarities to the acids that are found in greater quantity (oleic acid); regarding the MO the composition is mostly of this acid (oleic acid), reaching values close to $60 \%$. In the PO the composition varies with two predominant FFAs (oleic acid and palmitic acid) with an average of $45 \%$ and $39 \%$ respectively.
The viscosity of the two oils also showed similarity, with mean values close to $35 \mathrm{~mm}^{2} \mathrm{~s}^{-1}$. The viscosity of the oils is a determining factor so that they are not used directly in engines or machines, because the high viscosity affects the operation of the entire machinery structure. Thus, when there is a reduction of the viscosity after the transesterification reactions, it may indicate that there has been the conversion into ethyl or methyl esters [22].

Regarding the saponification number, Coimbra and Jorge [32] stated that this parameter is inversely proportional to the average molecular weight of the FFA present in the oil. Therefore, this parameter correlates the size of the fatty acid chains according to the type of the oil analyzed, which can be inferred from Table 1 that the FFA present in MO are heavier because they have more unsaturations, indicated by the high amount of acid, oleic acid (18:1), which is unsaturated. This same comparison can be made with the values of Iodine, which has a direct relation with the number of unsaturations that the oils have [22].

Finally, Table 1 shows the oxidative stability of each oil. PO has a higher stability than MO, and according to Silva et al. [2] oxidative stability is a parameter that indicates the presence of natural antioxidants, such as carotenoids, and this characteristic is desirable and interesting for raw materials that will be used to produce biodiesel as it will result in samples with greater chemical stability.

Therefore, the objective of this work was to subject PO and MO to homogeneous acid-catalyzed transesterification in the presence of ethanol and investigate the formation of esters by means of proton nuclear magnetic resonance $\left({ }^{1} \mathrm{H}\right.$ NMR), Raman spectroscopy, Fourier transform infrared spectroscopy (FT-IR), thermogravimetry (TG), and derivative thermogravimetry (DTG) measurements. Also, the crude and catalyzed oils were characterized using the acidity and viscosity indexes, kinematic viscosity, esters content, density and oxidative stability.

\section{Materials and methods}

\subsection{Materials and reagents}

The PO and MO were purchased from Mundo dos Óleos company. The sulfuric acid (95.0-98.0\% purity), ethyl alcohol (99.7\% purity), and isopropyl alcohol (99.8\% purity) were purchased from Isofar.

\subsection{Acidity index (AI) of the oils and biodiesels}

Before the transesterification reaction, the oils were characterized by their acidity index, which shows the amount of FFA in the sample. The AI was calculated according to the AOCS Ca $5 \mathrm{a}-40$ method, and measurements were carried out in triplicate. This method was also used to calculate the $\mathrm{AI}$ of the biodiesels.

\subsection{Sample preparation and transesterification reaction}

The samples were prepared by adding oil and ethanol in the ratio of $1: 30$. The proportion of the original transesterification equation is $1: 3$ but, to achieve higher conversions, it is necessary to increase the amount of alcohol. This also helps to prevent the reverse reaction [35]. Sulfuric acid was further added as a catalyst in a $10 \% \mathrm{w} / \mathrm{w}$ ratio.

The transesterification reactions were performed with magnetic stirring at $80^{\circ} \mathrm{C}$ reflux in a mineral oil bath. To verify the influence of the reaction time on the final conversion of the esters, the reactions were carried out for 4, 8, 12, and $24 \mathrm{~h}$.

After the reaction, the samples were transferred to a separating funnel to separate the biodiesel from the glycerin and other components. After this step, the produced biodiesel was washed three times with $15 \% \mathrm{w} / \mathrm{v}$ aqueous $\mathrm{NaCl}$ solution so that all impurities and other heavy components were removed.

The biodiesels samples are denoted BP4, BP8, BP12, and BP24 for 
Table 1

Physical and chemical properties of pequi and macaúba crude oils.

\begin{tabular}{|c|c|c|c|c|}
\hline Properties & & MO & $\mathrm{PO}$ & Refs. \\
\hline \multirow[t]{4}{*}{ Free fatty acids content (\%) } & Oleic Acid (C18:1) & $52-58$ & $34.2-55.87$ & {$[22,27-32]$} \\
\hline & Palmitic Acid (C16:0) & $22.1-25$ & $31.4-46.6$ & {$[22,27-32]$} \\
\hline & Linoleic Acid (C18:2) & $9.7-15.7$ & $13.3-15.6$ & {$[22,27-32]$} \\
\hline & Steriacid (C18:0) & $1.08-5$ & $2.2-3.9$ & {$[22,27-32]$} \\
\hline Viscosity $\left(\mathrm{mm}^{2} \mathrm{~s}^{-1}\right) 40^{\circ} \mathrm{C}$ & & $33-41.9$ & $34.61-35$ & {$[2,14,22,28]$} \\
\hline Saponification value $\left(\mathrm{mg} \mathrm{KOH} \mathrm{g}^{-1}\right)$ & & $178.5-206$ & $198.48-205.42$ & {$[27,32-34]$} \\
\hline Iodine value $\left(\mathrm{g} \mathrm{I}_{2} 100 \mathrm{~g}^{-1}\right)$ & & $76,94-80$ & $55.05-71.97$ & {$[22,27,31,32]$} \\
\hline Oxidative stability (h) & & $4.87-10.7$ & 14.4 & {$[2,28,32]$} \\
\hline
\end{tabular}

those obtained from PO and BM4, BM8, BM12, and BM24 for those obtained from $\mathrm{MO}$ according to the reaction times.

\subsection{Viscosity analysis}

\subsubsection{Kinematic viscosity $(v)$}

The kinematic viscosity of the biodiesel was calculated using the NBR 10441 standard [36], and a Herzog HVU 490 automatic viscometer was used. The run-off times were calculated at 40 and $100{ }^{\circ} \mathrm{C}$, with a maximum temperature variation of $0.02^{\circ} \mathrm{C}$, and $20 \mathrm{~mL}$ of the sample was used for each measurement.

\subsubsection{Viscosity index (VI)}

The VI of the biodiesels was calculated according to the NBR 14358 standard [37]. Raw oils from Pennsylvania and the Gulf of Mexico were used as standards, having IR values of 100 and 0 , respectively.

\subsection{Density}

Density analysis was performed using approximately $2 \mathrm{~mL}$ of the sample that was introduced into an oscillating tube. The change in oscillation frequency caused by the mass change in the tube was used, in combination with calibration data, and it determined the specific mass, density or ${ }^{\circ}$ API of the sample.

\section{6. ${ }^{1} H$ NMR analysis}

The ${ }^{1} \mathrm{H}$ NMR spectra of the biodiesel were obtained using a Bruker Avance III HD 14 T spectrometer with a frequency of $600 \mathrm{MHz}$, and deuterated chloroform $\left(\mathrm{CDCl}_{3}\right)$ was used as solvent and reference. The spectrometer was equipped with an automated triple broadband (ATB) probe with a diameter of $5 \mathrm{~mm}$. A $1.0 \mathrm{~s}$ pulse interval was used with 16 transients.

The ${ }^{1} \mathrm{H}$ NMR spectra were used to calculate the reaction conversion following the method of Ghesti et al. [10]. In this method, two peaks are selected for the calculations. Eq. (1) shows the calculation.

$\% C_{E E}=\frac{4\left(I_{T A G+E E}-I_{T A G}\right)}{4\left(I_{T A G+E E}-I_{T A G}\right)+12 I_{T A G}}$

Here, $\mathrm{C}_{\mathrm{EE}}$ represents the conversion into ethyl esters (biodiesel). $\mathrm{I}_{\mathrm{TAG}+\mathrm{EE}}$ is the integrated peak area between 4.10 and $4.20 \mathrm{ppm}$ where the glycerol methyl hydrogen atoms and the $\mathrm{CH}_{2}$ groups belonging to the formed ethoxy group can be found; the presence of these peaks indicates the production of biodiesel. $\mathrm{I}_{\mathrm{TAG}}$ is the integrated peak area between 4.25 and $4.35 \mathrm{ppm}$, where only non-transesterified glycerol methyl hydrogen atoms are found. The constants 4 and 12 appear in Eq. 1 because of the four hydrogen atoms of glycerol in triglyceride molecules and the six hydrogen atoms in the ethyl ester, respectively.

\subsection{Ester content}

Quantitation of C18 carbon chain predominant in biodiesel samples was performed according to ABNT NBR 15764 standard [38], using an analytical curve prepared with methyl octadecenoate. The samples were analyzed by gas chromatography, using the external standardization method to quantify the esters present in biodiesel, regardless of the type of raw material used in its production. The equipment used was an Agilent $6890 \mathrm{GC}$ with an automatic on-column injector, and flame ionization detector, with injection volume of 0.5 microliters, $30 \mathrm{~m} \times 0.32 \mathrm{~mm} \times 0.1 \mu \mathrm{m}$ DB5-HT column. The running occurred at a constant flow rate of $3.0 \mathrm{~mL} \mathrm{~min}^{-1}$. The temperature ramp started at $50^{\circ} \mathrm{C} \mathrm{min}^{-1}$, heated to $180^{\circ} \mathrm{C}$ at $15^{\circ} \mathrm{C} \mathrm{min}^{-1}$ and then a new heating up to $230{ }^{\circ} \mathrm{C}$ at $7^{\circ} \mathrm{C} \mathrm{min}^{-1}$, with the last step up to $380^{\circ} \mathrm{C}$ at $20^{\circ} \mathrm{C} \mathrm{min}{ }^{-1}$, remaining at this temperature for $10 \mathrm{~min}$. The flows of hydrogen, air, and nitrogen (makeup) were 35,350 and $35 \mathrm{~mL} \mathrm{~min}^{-1}$.

\subsection{Oxidative stability}

Oxidative stability tests were performed according to EN 15751 [39]. The test was performed at ANP, in a Metrohm Rancimat 743 equipment, at $110{ }^{\circ} \mathrm{C}, 10 \mathrm{~L} \mathrm{~h}^{-1}$ airflow and electrodes for readings of $0 \mu \mathrm{S} \mathrm{cm}^{-1}$ to $300 \mu \mathrm{S} \mathrm{cm}^{-1}$. $50 \mathrm{~mL}$ of demineralized water and $3 \mathrm{~g}$ of the sample were used for the analysis.

\subsection{Dispersive Raman analysis}

The Raman spectra were acquired using a WITec Confocal Raman Microscope (WITec alpha300 RA, Ulm, Germany) with an XTRA II single-frequency diode laser at wavelength and laser power of $785 \mathrm{~nm}$ and $400 \mathrm{~mW}$, respectively. The signal was detected by a thermoelectrically-cooled charge-coupled device. For the biodiesel analysis, samples were deposited on the surface of aluminum foils. All spectra were acquired in spectroscopy mode using a Zeiss EC Epiplan-Neofluar $20 \times$ air objective. The integration time was set to $0.05 \mathrm{~s}$ with 100 acquisitions for each evaluated sample following by spectra processing.

\subsection{TG and DTG analyses}

The TG curves of the biodiesels were obtained using Shimadzu DTG$60 \mathrm{H}$ TGA. In each measurement, approximately $10 \mathrm{mg}$ of each sample was used in a platinum cell. The analysis was performed in a synthetic air atmosphere $\left(30 \mathrm{~mL} \mathrm{~min}^{-1}\right)$ at $10^{\circ} \mathrm{C} \mathrm{min}^{-1}$ from 25 to $300^{\circ} \mathrm{C}$. The thermal decomposition temperatures $\left(T_{\mathrm{d}}\right)$ were obtained from the DTG curves.

\subsection{FT-IR analysis}

The FT-IR spectra were obtained using a Spectrum Two spectrophotometer from PerkinElmer operating in transmission mode in the range of $4000-400 \mathrm{~cm}^{-1}$, at room temperature. The resolution was $4 \mathrm{~cm}^{-1}$ averaged over 4 scans. 


\section{Results and discussion}

\subsection{Acidity index (AI)}

Free fatty acids (FFA) in the sample are detrimental to the reaction because they can react with the catalyst and be transformed into undesirable compounds. Thus, the FFA concentration must be controlled to obtain high-quality biodiesels. Based on the AI, the catalytic route can be chosen [40-42].

For AI values up to $6 \mathrm{mg} \mathrm{KOH} \mathrm{g}^{-1}$ oil, a homogeneous base-catalyzed reaction is appropriate. For higher AI values, homogeneous acid catalysis is more suitable because the high acidity value can result in side reactions during transesterification, such as saponification [43]. The PO and MO had AI values of 0.842 and $18.23 \mathrm{mg} \mathrm{KOH} \mathrm{g}^{-1}$ oil, respectively. Thus, homogeneous acid catalysis was chosen because of the high AI of MO. Santos et al. [44] and Barbosa et al. [45] found similar values for PO, i.e., lower than $6 \mathrm{mg} \mathrm{KOH} \mathrm{g}^{-1}$ oil. For MO, Coimbra and Jorge [32] found values higher than $6 \mathrm{mg} \mathrm{KOH} \mathrm{g}^{-1}$ oil: 9 to $11 \mathrm{mg} \mathrm{KOH} \mathrm{g}{ }^{-1}$ oil; these values are consistent with those found in this work.

The AI values ( $\mathrm{mg} \mathrm{KOH} \mathrm{g}^{-1}$ ) of the biodiesels formed by the transesterification reaction are listed in Table 2.

According to the ANP, the maximum acceptable AI for biodiesel is $0.5 \mathrm{mg} \mathrm{KOH} \mathrm{g}^{-1}$ [46]. Thus, only BP24 was within this limit, i.e., $0.28 \mathrm{mg} \mathrm{KOH} \mathrm{g}^{-1}$ biodiesel. Similar AI values for BP have been reported: $0.57 \pm 0.05 \mathrm{mg} \mathrm{KOH} \mathrm{g}^{-1}$ biodiesel [2] and $0.78 \mathrm{mg} \mathrm{KOH} \mathrm{g}^{-1}$ biodiesel [47]. For BM4 and BM24, the values obtained were high, probably because of the presence of large amounts of FFAs, as indicated by the high AI value of the crude oil.

Also, the transesterification reactions with acid route showed that although the oils have high AI values, the acid catalyst helps to reduce the volume of FFAs, and thus the AI value reduces after biodiesel production. For the PO, the reduction of the AI of the oil to the biodiesel was $66.7 \%$ and $13 \%$ for OM. Souza et al. [27] used an acid catalysis in a reactor under pressure and obtained a reduction of $88.07 \%$ in the AI of macaúba oil, this value differs from that obtained in this work due to the use of different reaction parameters, mainly the pressure, where the authors used $70 \mathrm{psi}$ in the reaction.

\subsection{Kinematic viscosity and viscosity index}

As reported by Mahmudul et al. [4], the kinematic viscosity is a parameter that analyzes the resistance of a liquid to flow. The VI indicates viscosity variation with temperature. Also, the kinematic viscosity is one of the most important parameters when it comes to analyzes the use of biodiesel in engines. Viscosity is directly related to fuelburning efficiency, as is the lubrication and automation of engines. Biodiesel with high viscosity value tends to resist more when it combusted and therefore require more energy, leading to the emission of more pollutant gases and smoke [48]. The kinematic viscosity and viscosity index values obtained for biodiesel are shown in Table 3.

The ANP limits the kinematic viscosity variation at $40{ }^{\circ} \mathrm{C}$ of biodiesel to 3 to $6 \mathrm{~mm}^{2} \mathrm{~s}^{-1}$. Of the samples analyzed, only BP4 did not fit within this limit because the conversion of this sample was only $50 \%$ (Section 3.3), i.e., much crude oil remained in the sample, resulting in a high viscosity variation. According to Mahmudul et al. [4], the kinematic viscosity of crude oils tends to be higher than those of biodiesel. A similar value was obtained for the biodiesel of MO: $3.1 \mathrm{~mm}^{2} \mathrm{~s}^{-1}$ at

Table 2

$\mathrm{AI}$ of PO and MO biodiesels (BP and BM, respectively).

\begin{tabular}{lll}
\hline Reaction time $(\mathrm{h})$ & $\mathrm{BP}\left(\mathrm{mg} \mathrm{KOH} \mathrm{g}^{-1}\right)$ & $\mathrm{BM}\left(\mathrm{mg} \mathrm{KOH} \mathrm{g}^{-1}\right)$ \\
\hline 4 & $0.83 \pm 0.01$ & $16.6 \pm 0.04$ \\
24 & $0.28 \pm 0.02$ & $15.8 \pm 0.04$ \\
\hline
\end{tabular}

Table 3

Kinematic viscosity and viscosity index values for 4 and $24 \mathrm{~h}$ biodiesel samples.

\begin{tabular}{llll}
\hline Samples & $\nu_{40}{ }^{\circ} \mathrm{C}\left(\mathrm{mm}^{2} \mathrm{~s}^{-1}\right)$ & $\nu_{100}{ }^{\circ \mathrm{C}}\left(\mathrm{mm}^{2} \mathrm{~s}^{-1}\right)$ & $\mathrm{VI}$ \\
\hline BP4 & 11.9 & 3.4 & 178.2 \\
BP24 & 4.1 & 1.8 & 226.9 \\
BM4 & 3.8 & 1.4 & 111.3 \\
BM24 & 3.5 & 1.3 & 73.1 \\
\hline
\end{tabular}

$40{ }^{\circ} \mathrm{C}[27]$.

As reported by Folayan et al. [48], biodiesels tend to suffer a decrease in their kinematic viscosity values when the triglycerides are transesterified, and the ethyl esters obtained, since its saturated chains are transferred to the biodiesel molecule, as happened with the viscosity values obtained in this work.

Concerning the VI, BP24 showed the most stable viscosity of all the biodiesels analyzed. In this sample, there was only $56.1 \%$ viscosity reduction with increase in temperature, compared to $63.1 \%$ of the MO biodiesel; of these samples, BM4 presented greater stability.

\subsection{Density}

Fuel density directly affects engine performance by changing the amount of injected mass, fuel combustion characteristics, and other characteristics such as cetane number and heating value [49]. The density limit for biodiesel ranges from $850-900 \mathrm{~kg} \mathrm{~m}^{-3}$ [46] to $860-900 \mathrm{~kg} \mathrm{~m}^{-3}$ [50]. Table 4 shows the values obtained for the 4 samples analyzed, where all meet the required limit. Comparing the samples to each other, BM obtained lower values than those of BP. This indicates that BM esters have lower carbon chains than BP esters since density is directly related to the molecular structure of biodiesel $[27,51]$. Also, density serves as a quality parameter for biodiesel as it indicates the presence of impurities such as alcohol and adulterating substances $[2,27]$. Thus, both samples are of good quality as they are within the standard according to two norms.

Similar results were found by Souza et al. [27] in the production of ethyl esters from macaúba oil, at a density of $875 \mathrm{~kg} \mathrm{~m}^{-3}$ and by Cardoso et al. [52], which obtained for pequi biodiesel a value of $890 \mathrm{~kg} \mathrm{~m}^{-3}$.

\section{4. ${ }^{1} \mathrm{H}$ NMR analysis}

The ${ }^{1} \mathrm{H}$ NMR spectra obtained for the PO and MO are shown in Fig. 1. Only the spectra for the 4 and $24 \mathrm{~h}$ reactions are shown because of the similarity of the spectra of other reactions with that of the $24 \mathrm{~h}$ reaction.

In the analysis of biodiesel produced from the two oils in this study, the main peaks were identified between 4.10 and $4.35 \mathrm{ppm}$. The signal identifying the presence of ethyl esters is a quadruplet between 4.10 and $4.20 \mathrm{ppm}$, which arises from methylene hydrogen atoms of glycerol and the hydrogen atoms of the ethoxy group $\left(\mathrm{CH}_{3} \mathrm{CH}_{2} \mathrm{O}-\right)$. Between 4.25 and $4.35 \mathrm{ppm}$, there is a pair of doublets indicating the methylene hydrogen atoms of glycerol, indicating the presence of non-transesterified oil in the reaction. In the spectrum of BM4, these two peaks are not present, indicating that the oil was completely transesterified, as shown in Fig. 1b. In the spectrum of the PO sample obtained after $4 \mathrm{~h}$ reaction

Table 4

Quantitative and qualitative parameters of the biodiesel obtained after the transesterification step.

\begin{tabular}{llllll}
\hline Sample & BP4 & BP24 & BM4 & BM24 & ANP 45/14 limits \\
\hline Density $\left(\mathrm{kg} \mathrm{m}^{-3}\right)$ & 898.6 & 882.9 & 874.2 & 867.1 & $850-900$ \\
Ester content (\%) & 60.7 & 97.9 & 91.1 & 96.7 & 96.5 \\
Induction period (h) & 0.20 & 10.95 & 10.28 & 10.55 & 12 \\
\hline
\end{tabular}




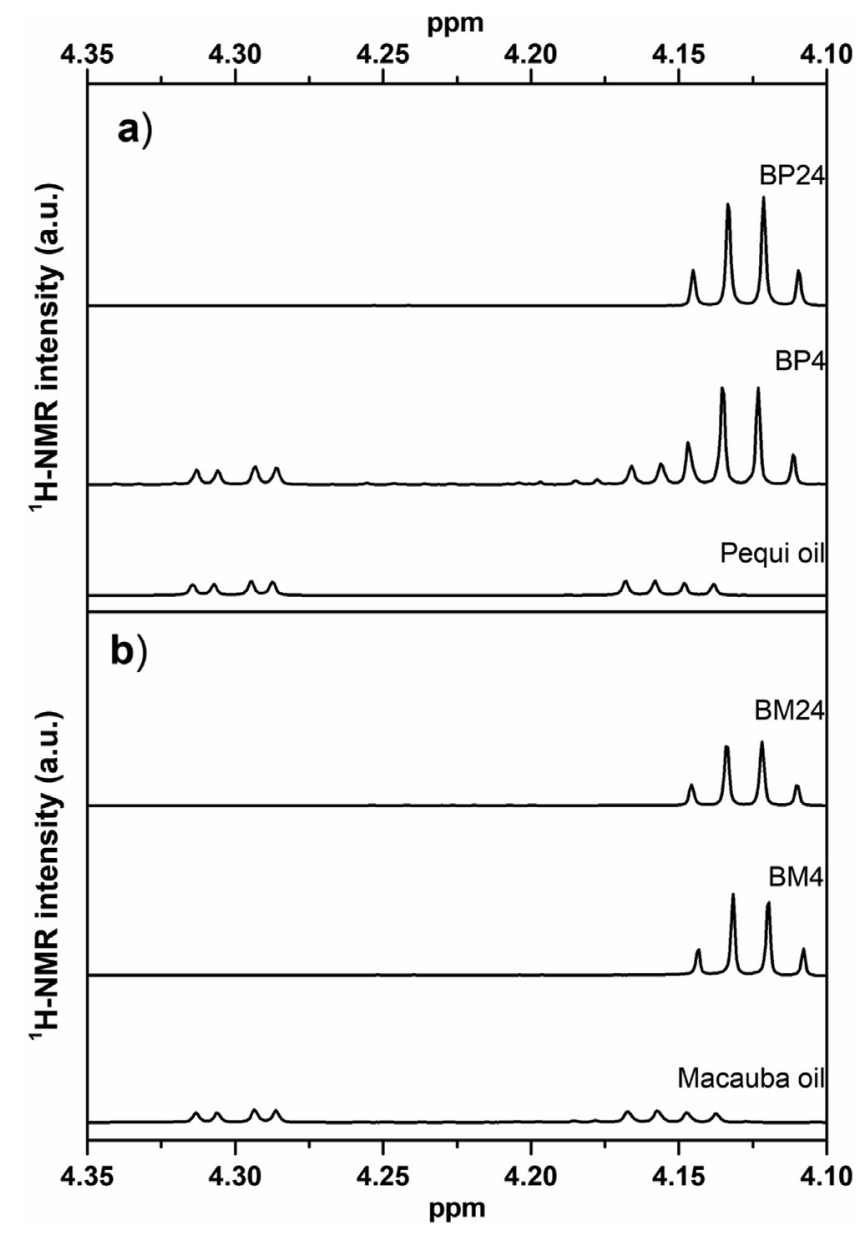

Fig. 1. ${ }^{1} \mathrm{H}$ NMR spectra: a) PO and its biodiesel and b) MO and its biodiesel.

(Fig. 1a), an overlap of peaks between 4.10 and $4.20 \mathrm{ppm}$ can be observed, indicating the presence of a mixture of oil and the ethyl esters formed. Similar ${ }^{1} \mathrm{H}$ NMR peaks for biodiesel obtained from PO have been reported $[2,10]$.

In addition to the identification of the formed ethyl esters, ${ }^{1} \mathrm{H}$ NMR analysis can also provide the rate of conversion of the transesterification reaction. The rate is calculated from the integrated peak areas using Eq. (1). For PO, the reaction time influenced the conversion rate. After $4 \mathrm{~h}$, the conversion was $50 \%$, whereas, after $24 \mathrm{~h}$, the conversion was $95 \%$. For MO, the reaction time did not influence the conversion, so both the 4 and $24 \mathrm{~h}$ reactions showed a conversion rate of $98 \%$. Although the AI of MO indicates the presence of a large amount of FFA, the conversion rate is high, which means that the fatty acids were converted to ethyl esters. Similar results were obtained by Rosset et al. [53] with basic catalysis of soybean oil in the presence of ethanol. The spectra presented the same characteristics of quadruplets and doublets in the same signals, with the presence of two doublets in $4.10-4.20 \mathrm{ppm}$ (with $50 \%$ biodiesel).

\subsection{Esters content}

Ester content analysis in biodiesel samples is a characterization that quantifies the percentage of mass concerning to the total mass of the sample which contains methyl or ethyl esters. It is one of the most important analyzes in the biofuels industry because it presents the number of intermediate compounds such as monoglycerides, diglycerides, and triglycerides that have not been converted into esters. Also, this analysis shows the amount of glycerol present in the sample, and since the more glycerol molecules present in the sample, the lower the percentage of ethyl or methyl esters, this analysis become important to the biofuels [54].

The ANP states that the minimum acceptable ester content for a sample to be considered a biodiesel is $96.5 \% \mathrm{w} / \mathrm{w}$. Table 4 shows the results obtained for BP4, BP24, BM4 and BM24.

Table 4 results indicate that the highest yields were obtained with $24 \mathrm{~h}$ reaction and agree with the results of ${ }^{1} \mathrm{H}$ NMR analysis. BP4 presented the lowest value among the samples and its low level of esters can be explained by its low conversion (50\%) compared to the other samples (98\%). In addition, the results indicate that the biodiesels obtained with the longest reaction time $(24 \mathrm{~h})$ were in accordance with ANP 45/14 [46] resolution specifications and can be considered a biodiesel.

Ferreira et al. [22] obtained biodiesel from pequi using basic homogeneous transesterification, and at the end they observed values similar to those of this study for the esters content in the sample. They obtained biodiesel with $98 \%$ content of methyl esters with higher concentration of linoleic acid (18:2). Souza et al. [27] obtained biodiesel with $93.9 \%$ ester content from esterification of macáuba pulp oil in the presence of ethanol, and these results are also in agreement with those obtained in this work. Also, they showed that the biodiesel obtained from macaúba presented higher oleic acid content (18:1).

Despite the satisfactory results, the fatty acid profile of the MO reaction showed significant amounts of light esters with odd chains, which indicates many volatile esters. Therefore, these biodiesels have a higher storage sensitivity, which can lead to a loss of its components. This problem can be remedied with the addition of stabilizing additives and antioxidants in the biodiesel produced from macaúba.

\subsection{Oxidation stability}

The oxidation stability of biodiesel is directly related to double carbon chain connections and the degree of unsaturation of alkyl esters present, where the more unsaturated, the more likely a molecule to thermally and oxidatively degrade, thus forming insoluble products that can cause clogging in injection system of engine fuel [51,55]. Until August 2019 the minimum time set by the ANP at $110^{\circ} \mathrm{C}$ was $8 \mathrm{~h}$, but in September this parameter changed to $12 \mathrm{~h}$ [46]. The standard adopted by the European Union (EN 14214) is $6 \mathrm{~h} \mathrm{[50].}$

Table 4 shows the results obtained for BP and BM. Among the samples studied, the ones that most closely match the new ANP standard are the biodiesel of $24 \mathrm{~h}$ for both feedstocks, which is coherent since this reaction time got higher ester conversion. In addition, they meet the standards required by the European Union. Silva et al. [2] also failed to obtain values within the ANP limit for pequi oil biodiesel; however they clarified the possibility of using antioxidant to make the fuel more stable.

\subsection{Dispersive Raman spectroscopy}

To identify the presence of ethyl esters after transesterification in the Raman spectra, the identification of stretches of specific bands of the ester molecule is required. Ghesti et al. [10] quantified the presence of biodiesel using Raman spectroscopy and validated their method and its reliability.

Figs. 2 and 3 show the spectra acquired from the oil samples and their respective biodiesels. The spectra have a high peak density and bands between 800 and $1500 \mathrm{~cm}^{-1}$, but previous studies using this technique to quantify biodiesel did not report the specific bands corresponding to ethyl esters in this area $[10,56]$. In the spectra of the esters obtained from the transesterification of PO and MO (Figs. 2 and 3 ), the band at $870 \mathrm{~cm}^{-1}$ increased with increasing reaction time. This band was reported by Sahoo et al. [57] to be near $873 \mathrm{~cm}^{-1}$ and was identified as the C-O-C stretch band present in the ethyl ester molecule.

Another relevant band was identified between 300 and $400 \mathrm{~cm}^{-1}$, and it is possible to observe an increase in the intensity of the peak at 


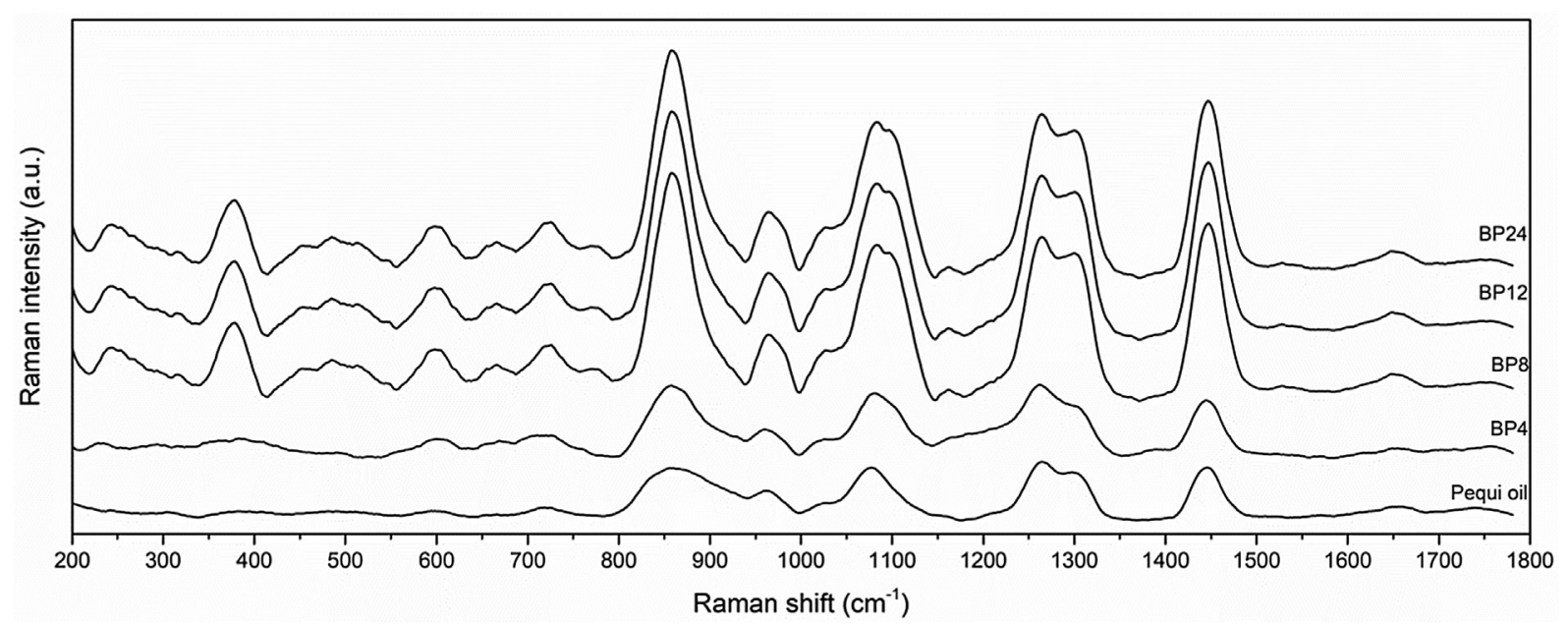

Fig. 2. Raman spectra of PO and its respective biodiesels.

$370 \mathrm{~cm}^{-1}$ in both spectra. In Fig. 2, this peak is only visible in the BP8 spectrum because this sample showed more than $90 \%$ biodiesel conversion efficiency, unlike BP4, which showed only 50\% conversion (Section 3.3). This band is related to the CO-O-C groups present in ethyl esters, indicating their formation [10].

The Raman spectra of the oils show differences in the peak positions and intensities because of the different fatty acid compositions; however, there are similarities between 800 and $1500 \mathrm{~cm}^{-1}$, where the spectra contain four main bands. The most common band is that between 1400 and $1500 \mathrm{~cm}^{-1}$, which corresponds to the $\mathrm{CH}_{3}$ group of the ethyl ester [58]. All such bands and stretches demonstrate the suitability of dispersive Raman spectroscopy to identify and quantify the presence of ethyl esters in samples.

\subsection{TG and DTG analysis}

Figs. 4 and 5 show the TG and DTG analyses of the transesterified oils (BP and BM, respectively) prepared at different reaction times.

As shown by the TG curves, there was only one thermal degradation step, which is also shown by the DTG peak. The same observation was made by Bezerra et al. [59] and Raslavičius et al. [60] who observed that biodiesel thermally decomposes in one step. Also, the maximum degradation temperatures were obtained: 243 and $205^{\circ} \mathrm{C}$ for BP and $\mathrm{BM}$, respectively. Similar values for BP and BM were found by Tutunea [61] and Vega-Lizama et al. [62]: 240 and $213^{\circ} \mathrm{C}$, respectively.

For BP4, the degradation temperature was different because only
$50 \%$ conversion to biodiesel was achieved. For this reaction, the mass loss was only $52.6 \%$, whereas, for the biodiesel samples, the mass losses were $95 \%$ with only $5 \%$ residual mass. BP4 also showed a difference in the initial degradation temperature $\left(\mathrm{T}_{\text {onset }}\right)$, which started at $237^{\circ} \mathrm{C}$, whereas, for the other reaction, the average was $222.7^{\circ} \mathrm{C}$, indicating higher thermal stability and suggesting that some FFAs were not transesterified. For BM, all reaction times yielded similar results: an average mass loss of $98 \%$ with $\mathrm{T}_{\text {onset }}$ around $178.07^{\circ} \mathrm{C}$ and a maximum degradation temperature around $205^{\circ} \mathrm{C}$, as determined by DTG.

Similar values for BM were found by Mothé et al. [63] for ethyl biodiesel obtained from residual oil: degradation occurred in only one step starting at $180^{\circ} \mathrm{C}$, and it had a loss of mass of $98 \%$. Bezerra et al. [59] obtained a $97 \%$ mass loss for sesame oil biodiesel in one degradation step beginning at $121^{\circ} \mathrm{C}$. Comparatively, BP was more thermally stable than $\mathrm{BM}$, as indicated by the higher mass loss temperature onset. This interpretation is supported by the work of Vega-Lizama et al. [62], who related the $\mathrm{T}_{\text {onset }}$ values for ester degradation with the type of fatty acid. They reported that when oleic acid makes up more than $50 \%$ of the $\mathrm{PO}$, the $\mathrm{T}_{\text {onset }}$ average was $218^{\circ} \mathrm{C}$. In general, the initial biodiesel degradation temperature occurs between 155 and $392^{\circ} \mathrm{C}$ [60].

\subsection{FT-IR analysis}

It was also investigated the presence of ethyl esters in the samples using FT-IR spectroscopy. This technique is advantageous because both solids and liquids can be analyzed without the need for pretreatment

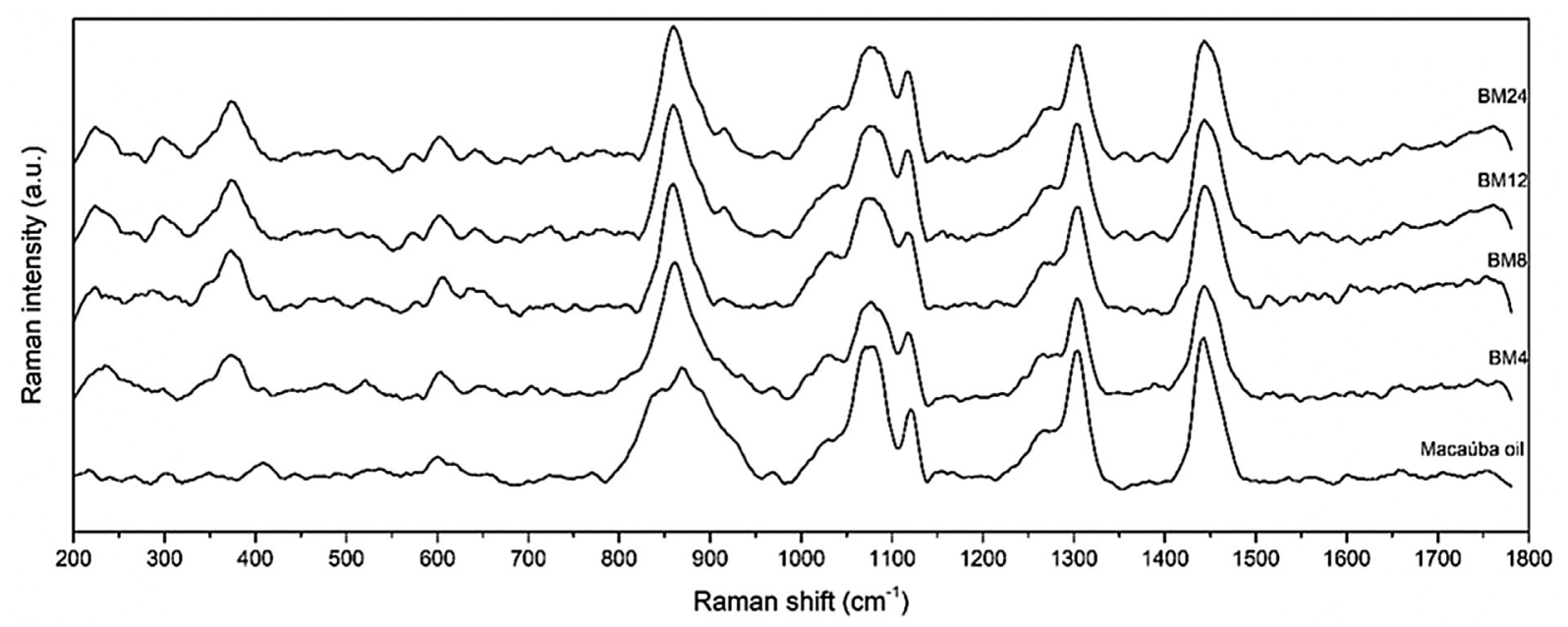

Fig. 3. Raman spectra of MO and its respective biodiesels. 


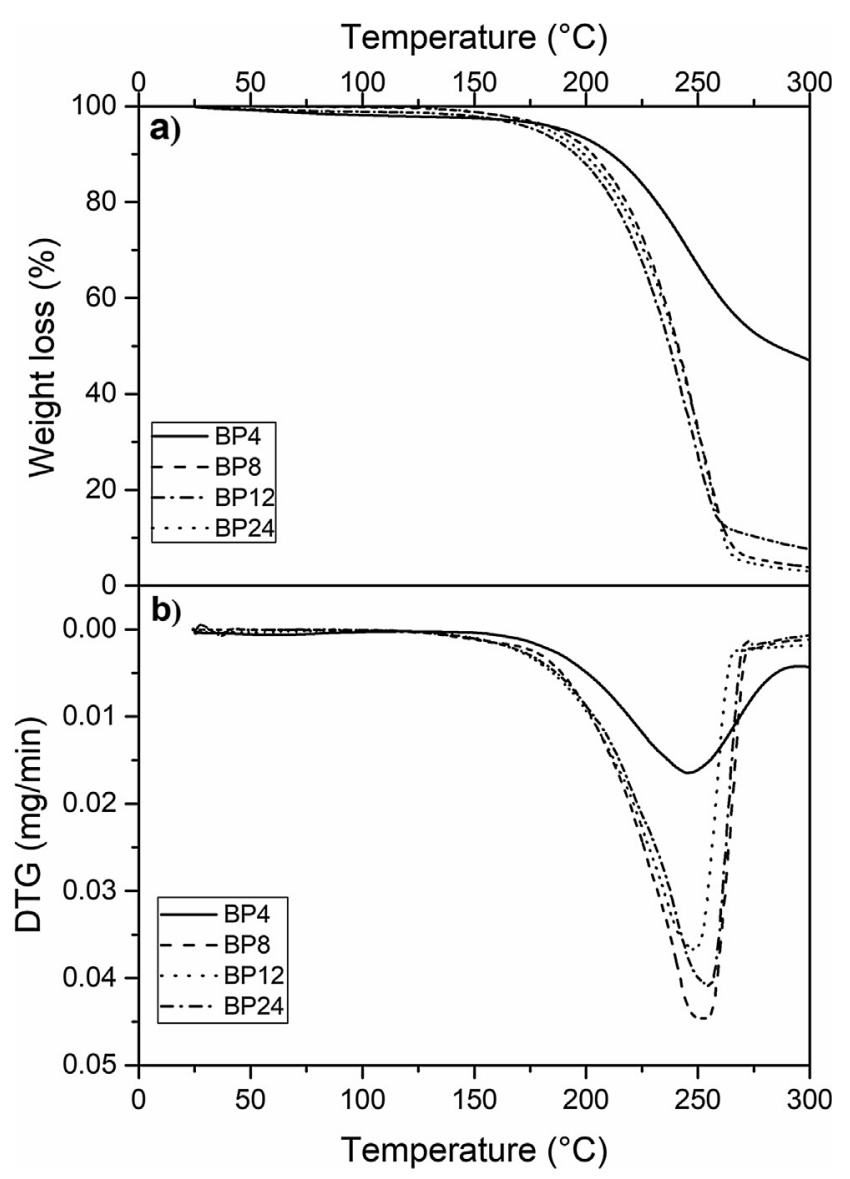

Fig. 4. (a) TG and (b) DTG curves of the PO biodiesel.

[64]. FT-IR is widely used in the monitoring of transesterification reactions for the quantification and identification of the substances present in the samples $[65,66]$.

Figs. 6 and 7 show the FT-IR spectra of PO and MO and their respective biodiesels.

According to Zhou et al. [65], who studied the oxidative degradation of biodiesel blends using FT-IR, the absorption band around $1743 \mathrm{~cm}^{-1}$ can be attributed to the $\mathrm{C}=\mathrm{O}$ group of the ethyl esters. This result was also obtained by Li et al. [66], and the band at $1742 \mathrm{~cm}^{-1}$ was attributed to the $\mathrm{C}=\mathrm{O}$ bonds in their study of the thermal degradation of biodiesel obtained from peanut oil. This main absorption band can be used as an indicator of biodiesel production because the bands between 1800 and $1700 \mathrm{~cm}^{-1}$ are attributed to the carbonyl groups of the formed esters [67]. This band was also observed in the BP and BM samples, as shown in Figs. 6 and 7, respectively, and the most intense peak was at $1737 \mathrm{~cm}^{-1}$. This peak at $1737 \mathrm{~cm}^{-1}$ was also observed by Niu et al. [68], who used FT-IR to characterize the ethyl esters formed from oleic acid, the major fatty acid in PO that is also present in MO.

Other absorption bands that can be used to identify the presence of ethyl esters include the band at $1034 \mathrm{~cm}^{-1}$ present in the two spectra (Figs. 6 and 7); this band is only present in the spectra of transesterified oils, and its area increases with an increasing amount of ethyl ester in the sample. As shown in the spectrum of BP4 (Fig. 6), the band at $1034 \mathrm{~cm}^{-1}$ is less intense than those in the spectra of the other biodiesels (50\% conversion), which have the same conversion efficiency ( $98 \%$ conversion) (Section 3.3). In contrast, the band in the spectrum of BM4 is the same as those in the spectra of the other BM samples because all BM samples underwent the same conversion. The band at $1034 \mathrm{~cm}^{-1}$ is associated with the symmetrical vibration of the C-O-C group and is present only in transesterified oils that contain oleic acid;

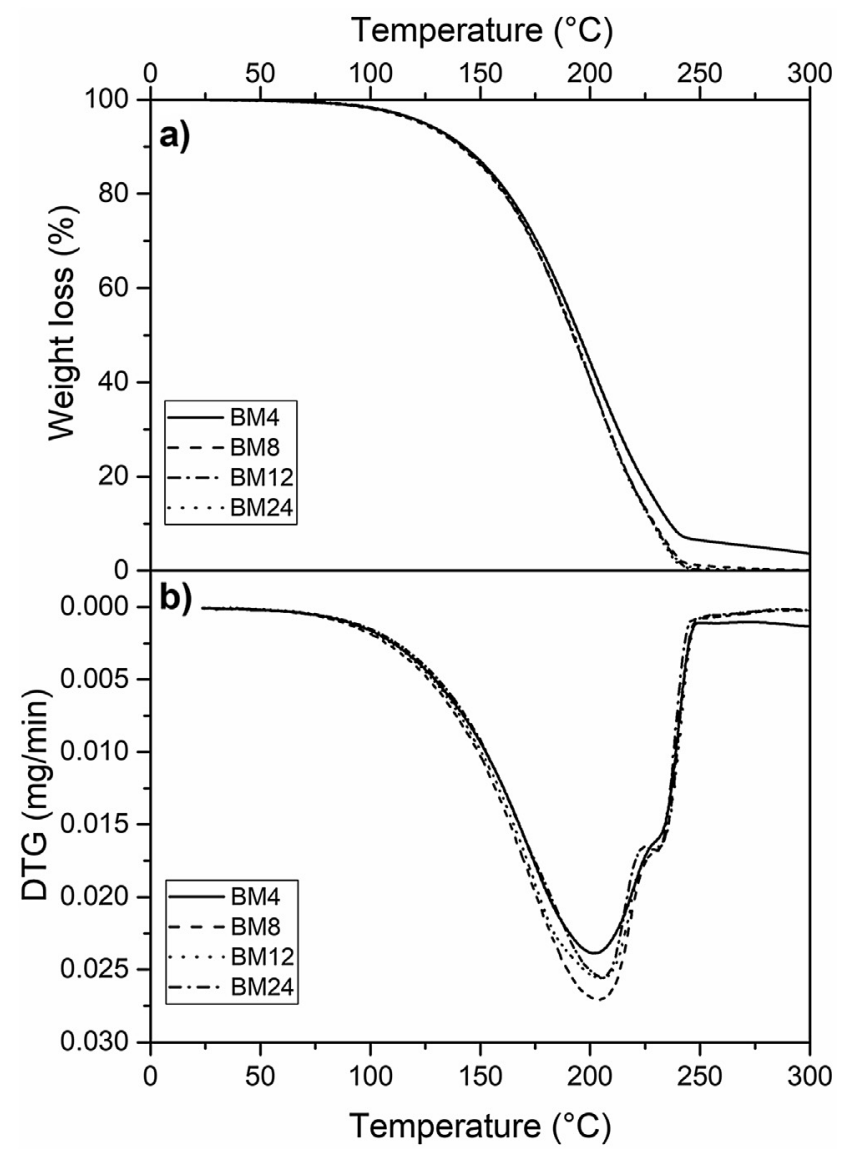

Fig. 5. (a) TG and (b) DTG curves of the MO biodiesel.

this band indicates the presence of ethyl esters [68].

Other bands that may indicate the presence of ethyl esters identified in Figs. 6 and 7 are listed in Table 5.

\section{Conclusions}

In this work, it was investigated the ethyl esters formed from pequi and macaúba oils by homogeneous acid catalysis in the transesterification reaction. For the AI of the crude oils, it was found that PO stayed in the limit $\left(0.842 \mathrm{mg} \mathrm{KOH}^{-1}\right)$, but MO had high value $\left(18.23 \mathrm{mg} \mathrm{KOH}^{-1}\right)$, indicating that the most suitable route is a homogeneous acid-catalyzed reaction, which was the route chosen for this work. Due to the large quantities of FFAs in the oil, the only biodiesel that had the limit stipulated by the ANP $\left(0.5 \mathrm{mg} \mathrm{KOH} \mathrm{g}^{-1}\right)$ was the BP24 $\left(0.28 \mathrm{mg} \mathrm{KOH} \mathrm{g}^{-1}\right)$. Regarding the kinematic viscosity, of all samples analyzed, BP4 was the only one that did not fit within limits indicated by the ANP because the conversion rate for this sample was about $50 \%$. The viscosity index showed that although both biodiesels have greater stability, the BP is more stable than the BM. By the density analysis it was verified that the macaúba and pequi biodiesel presented values within the ranges specified by the ANP and the European Union. With the transesterified oils, it was calculated the yield of the biodiesel conversion by means of ${ }^{1} \mathrm{H}$ NMR, and it was found for PO that the reaction time was a factor that influenced the conversion rate. In the $4 \mathrm{~h}$ reaction, there was a conversion of $50 \%$, whereas for $24 \mathrm{~h}$ the conversion was $95 \%$. For MO, the reaction time did not influence the conversion, so both the $4 \mathrm{~h}$ and the $24 \mathrm{~h}$ reactions showed a conversion rate of $98 \%$. The evaluation of biodiesel by oxidative stability showed that the biodiesel samples obtained in $24 \mathrm{~h}$ were the closest to the limit established by the ANP. However, the results obtained are within the standards required by the European Union. The results obtained from 


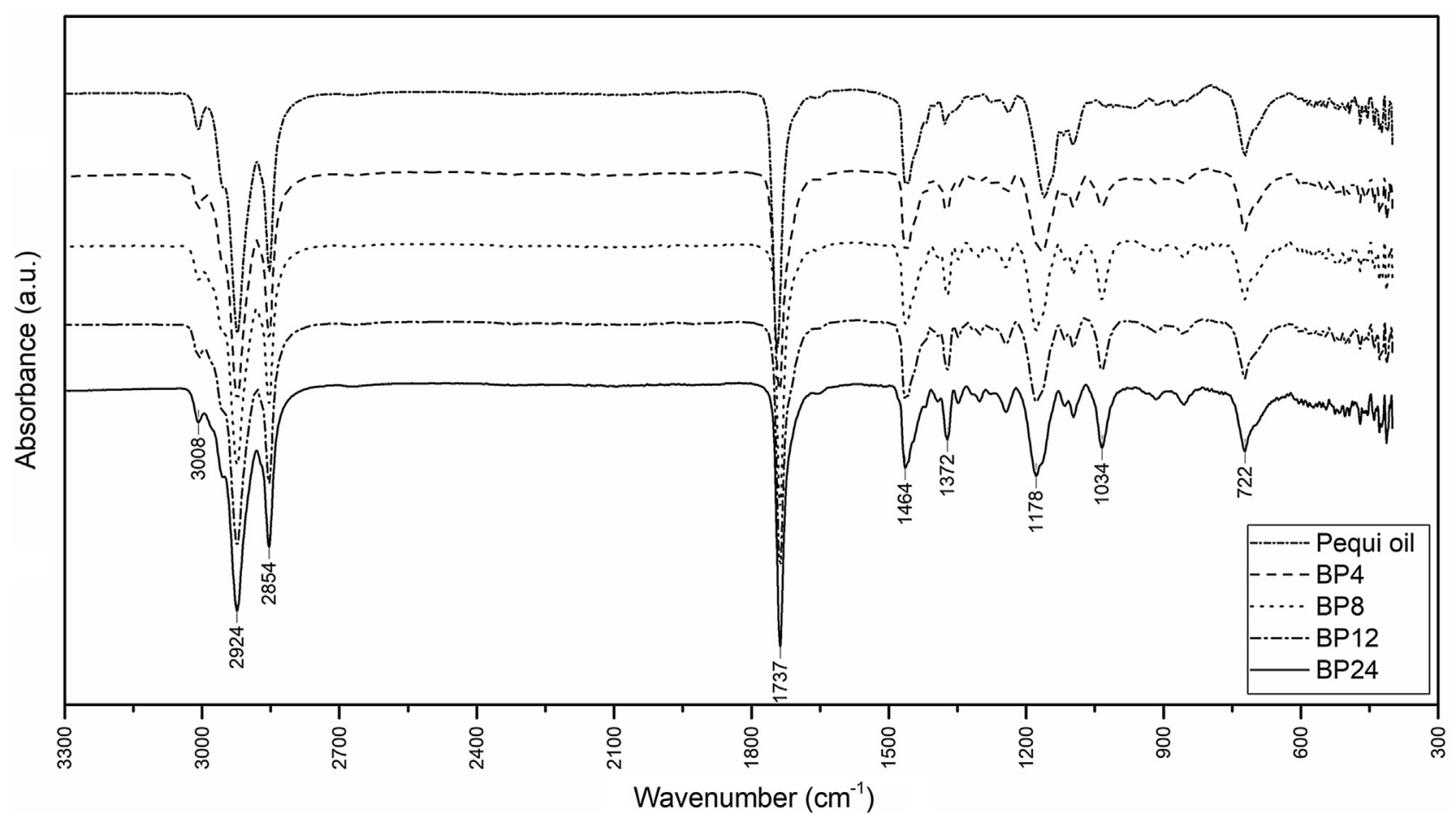

Fig. 6. FT-IR spectra of PO and its respective biodiesels.

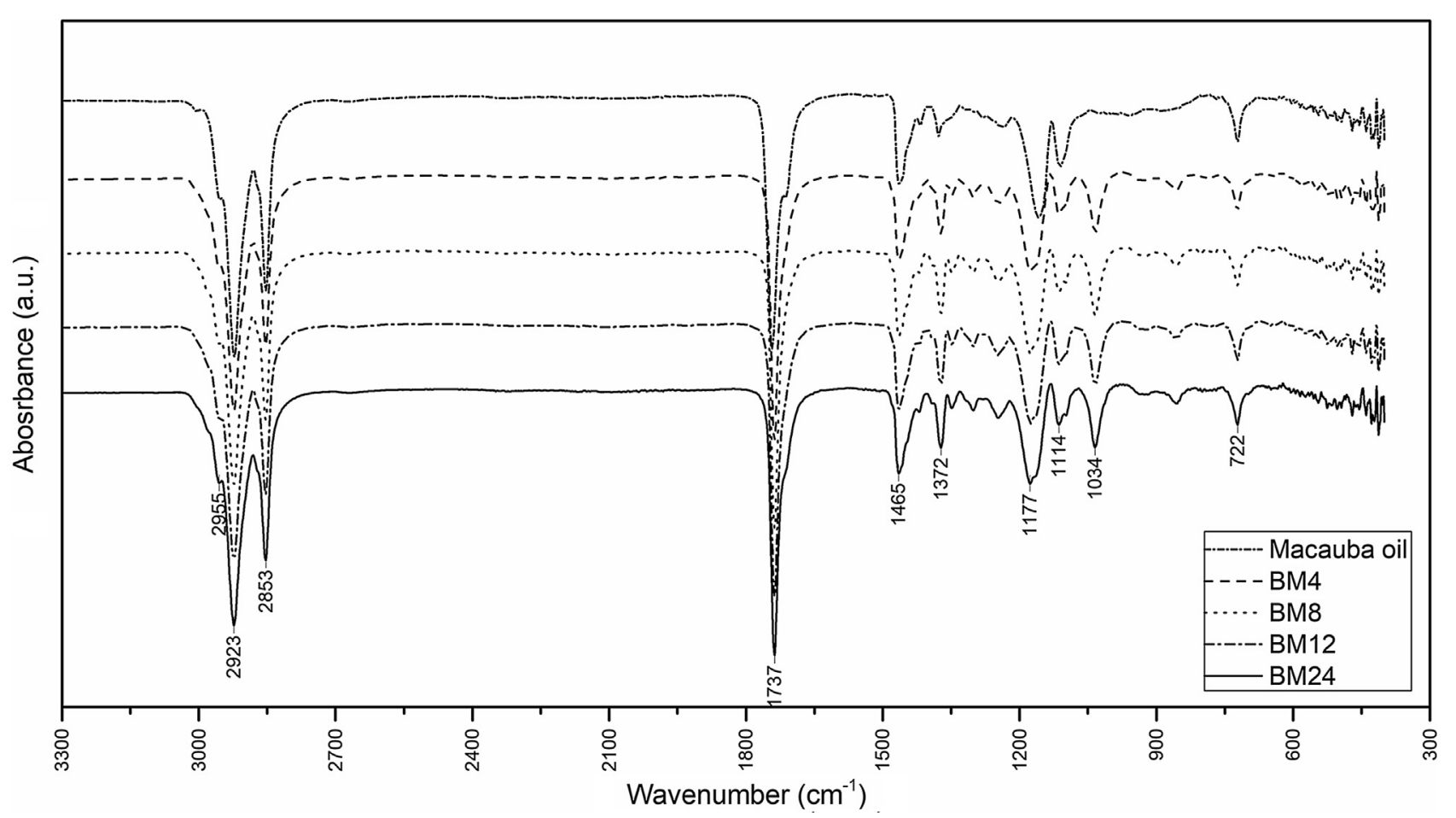

Fig. 7. FT-IR spectra of MO and its respective biodiesels.

the ester content showed that the highest yields in ethyl esters were obtained with $24 \mathrm{~h}$ reaction and are in agreement with the results of the ${ }^{1} \mathrm{H}$ NMR analysis, besides meeting the ANP 45/14 resolution specifications. From the Raman, FT-IR, and ${ }^{1} \mathrm{H}$ NMR analyzes, it was possible to verify the presence of ethyl esters. From TG and DTG, it was possible to see that for both biodiesels; thermal degradation occurred in a single step. The only biodiesel in which the reaction time interfered with the beginning of thermal degradation was BP4, indicating higher thermal stability and suggesting the presence of untransesterified fatty acids.
Although macaúba has advantages in the quantity of oil production, pequi is a better source for biodiesel production, because it presents a fuel of lower acidity and greater stability, besides the oil has less FFAs, allowing other catalytic routes. According to the results obtained, these biofuels can be classified as biodiesel.

\section{Acknowledgements}

The authors would like to thank the Instituto Federal de Brasília, 
Table 5

Characteristic absorption bands of the ethyl esters formed during the reaction.

\begin{tabular}{|c|c|c|c|c|}
\hline Group & $\mathrm{BP}\left(\mathrm{cm}^{-1}\right)$ & $\mathrm{BM}\left(\mathrm{cm}^{-1}\right)$ & $\begin{array}{l}\text { Reference } \\
\left(\mathrm{cm}^{-1}\right)\end{array}$ & References \\
\hline $\begin{array}{l}\text { Out-of-plane vibration of } \\
\text { C-H of the } \mathrm{CH}_{2} \text { group }\end{array}$ & 722 & 722 & $\begin{array}{l}722 \\
723\end{array}$ & {$[66,68]$} \\
\hline $\begin{array}{l}\text { Asymmetric axial } \\
\text { vibration of } \mathrm{C}-\mathrm{O}-\mathrm{C}\end{array}$ & 1178 & 1177 & $\begin{array}{l}1175 \\
1183\end{array}$ & {$[67,69]$} \\
\hline $\begin{array}{l}\text { Symmetric vibration of } \\
\text { H-C-H }\end{array}$ & 1372 & 1372 & 1377 & [68] \\
\hline $\begin{array}{l}\text { Vibration of the } \mathrm{CH}_{2} \\
\text { group }\end{array}$ & 1464 & 1465 & 1463 & [68] \\
\hline $\begin{array}{l}\text { Axial vibration of } \mathrm{C}-\mathrm{H} \text { in } \\
\text { the } \mathrm{CH}_{2} \text { group }\end{array}$ & 2854 & 2853 & $\begin{array}{l}2853 \\
2853\end{array}$ & {$[66,68]$} \\
\hline $\begin{array}{l}\text { Axial vibration of } \mathrm{C}-\mathrm{H} \text { in } \\
\text { the } \mathrm{CH}_{3} \text { group }\end{array}$ & 2924 & 2923 & $\begin{array}{l}2923 \\
2923\end{array}$ & {$[66,68]$} \\
\hline $\begin{array}{l}\text { Axial vibration of } \mathrm{C}-\mathrm{H} \text { in } \\
\text { olefin unsaturation }\end{array}$ & 3008 & - & 3009 & [68] \\
\hline
\end{tabular}

Embrapa Recursos Genéticos e Biotecnologia and ANP for the availability of equipment's for conducting the analyzes, and all the staff of University of Brasília, who helped and made available some space in the laboratory for the experiments.

\section{References}

[1] Cruz RP, Ferreira FB, Rodrigues FDÁ. Simulação e análise econômica da produção de biodiesel a partir de óleo de macaúba. J Eng Exact Sci 2017;3:533-60. https:// doi.org/10.18540/2446941603032017533.

[2] Silva TA, De Assunção RMN, Vieira AT, De Oliveira MF, Batista ACF. Methylic and ethylic biodiesels from pequi oil (Caryocar brasiliense Camb.): production and thermogravimetric studies. Fuel 2014;136:10-8. https://doi.org/10.1016/j.fuel. 2014.07.035.

[3] ANP. Resolução N. 30 de 23.06.2016 2016:7.

[4] Mahmudul HM, Hagos FY, Mamat R, Adam AA, Ishak WFW, Alenezi R. Production, characterization and performance of biodiesel as an alternative fuel in diesel engines - a review. Renew Sustain Energy Rev 2017;72:497-509. https://doi.org/10. 1016/j.rser.2017.01.001.

[5] Varão LHR, Silva TAL, Zamora HDZ, Pasquini D. Vantagens E Limitações Do Sebo Bovino Enquanto Matéria-Prima Para a Indústria Brasileira De Biodiesel. Holos 2017;7:39. https://doi.org/10.15628/holos.2017.5010.

[6] Churchill GV, Srinivasan CA. Experimental investigations on combustion and emission characteristics of biodiesel blends in CI engine. Biomass Bioenergy 2017:1523-9.

[7] Brabo - Catala L, de Lemos LA, Mendes PCD. Estimation on biodiesel production utilizing contaminated peanuts in Brazil. Bioenergia Em Rev Diálogos 2017;7:77-97.

[8] Nikhom R, Tongurai C. Production development of ethyl ester biodiesel from palm oil using a continuous deglycerolisation process. Fuel 2014;117:926-31. https:// doi.org/10.1016/j.fuel.2013.10.018.

[9] Baiju B, Naik MK, Das LM. A comparative evaluation of compression ignition engine characteristics using methyl and ethyl esters of Karanja oil. Renew Energy 2009;34:1616-21. https://doi.org/10.1016/j.renene.2008.11.020.

[10] Ghesti GF, de Macedo JL, Resck IS, Dias JA, Dias SCL. FT-Raman spectroscopy quantification of biodiesel in a progressive soybean oil transesterification reaction and its correlation with1H NMR spectroscopy methods. Energy Fuels 2007;21:2475-80. https://doi.org/10.1021/ef060657r.

[11] de Souza NRD, Fracarolli JA, Junqueira TL, Chagas MF, Cardoso TF, Watanabe MDB, et al. Sugarcane ethanol and beef cattle integration in Brazil. Biomass Bioenergy 2019;120:448-57. https://doi.org/10.1016/j.biombioe.2018.12.012.

[12] Lopes ML, Paulillo SC de L, Godoy A, Cherubin RA, Lorenzi MS, Giometti FHC, et al. Ethanol production in Brazil: a bridge between science and industry. Braz J Microbiol 2016;47:64-76. https://doi.org/10.1016/j.bjm.2016.10.003.

[13] Turkkul B, Deliismail O, Seker E. Ethyl esters biodiesel production from Spirulina sp. and Nannochloropsis oculata microalgal lipids over alumina-calcium oxide catalyst. Renew Energy 2019;145:1014-9. https://doi.org/10.1016/j.renene.2019. 06.093.

[14] Belo Pasa TL, Souza GK, Diório A, Arroyo PA, Pereira NC. Assessment of commercial acidic ion-exchange resin for ethyl esters synthesis from Acrocomia aculeata (Macaúba) crude oil. Renew Energy 2019;146:469-76. https://doi.org/10.1016/j. renene.2019.06.025

[15] Fadhil AB, Al-Tikrity ETB, Ibraheem KK. Transesterification of bitter almond oil as a new non-edible feedstock with mixed alcohols system: parameter optimization and analysis of biodiesel. Waste Biomass Valoriz 2019;10:1597-608. https://doi.org/ 10.1007/s12649-017-0172-y.

[16] Loures CCA, Amaral MS, Da Rós PCM, Zorn SMFE, de Castro HF, Silva MB. Simultaneous esterification and transesterification of microbial oil from Chlorella minutissima by acid catalysis route: a comparison between homogeneous and heterogeneous catalysts. Fuel 2018;211:261-8. https://doi.org/10.1016/j.fuel.
2017.09.073.

[17] Tacias-Pascacio VG, Torrestiana-Sánchez B, Dal Magro L, Virgen-Ortíz JJ, SuárezRuíz FJ, Rodrigues RC, et al. Comparison of acid, basic and enzymatic catalysis on the production of biodiesel after RSM optimization. Renew Energy 2019;135:1-9. https://doi.org/10.1016/j.renene.2018.11.107.

[18] Ullah F, Dong L, Bano A, Peng Q, Huang J. Current advances in catalysis toward sustainable biodiesel production. J Energy Inst 2016;89:282-92. https://doi.org/ 10.1016/j.joei.2015.01.018.

[19] Gebremariam SN, Marchetti JM. Biodiesel production through sulfuric acid catalyzed transesterification of acidic oil: techno economic feasibility of different process alternatives. Energy Convers Manage 2018;174:639-48. https://doi.org/10. 1016/j.enconman.2018.08.078.

[20] Mathimani T, Uma L, Prabaharan D. Homogeneous acid catalysed transesterification of marine microalga Chlorella sp. BDUG 91771 lipid - an efficient biodiesel yield and its characterization. Renew Energy 2015;81:523-33. https://doi.org/10. 1016/j.renene.2015.03.059.

[21] Klink CA, Machado RB. A conservação do Cerrado brasileiro. Megadiversidade 2005;1:147-55. https://doi.org/10.1590/S0100-69912009000400001.

[22] Ferreira EN, Arruda TBMG, Rodrigues FEA, Arruda DTD, da Silva Júnior JH, Porto DL, et al. Investigation of the thermal degradation of the biolubricant through TGFTIR and characterization of the biodiesel - Pequi (Caryocar brasiliensis) as energetic raw material. Fuel 2019;245:398-405. https://doi.org/10.1016/j.fuel.2019. 02.006.

[23] Souza FG, Rodrigues FM, Rodrigues LG da SM. Extração artesanal e caracterização do óleo de macaúba (Acrocomia aculeata) em dois estágios de maturação. ENCICLOPÉDIA Biosf 2013;9:1188-95.

[24] Amaral F, Broetto F, Batistella CB, Jorge SMA. Extração e Caracterização Qualitativa do óleo da polpa e amendoas de frutos de Macaúba [Acrocomia aculeata (Jacq) Lodd. ex Mart] coletada na região de Botucatu. Energ Na Agric 2011;26:12-20. doi:10.17224/EnergAgric.2011v26n1p12-20.

[25] Navarro-Díaz HJ, Gonzalez SL, Irigaray B, Vieitez I, Jachmanián I, Hense H, et al. Macauba oil as an alternative feedstock for biodiesel: characterization and ester conversion by the supercritical method. J Supercrit Fluids 2014;93:130-7. https:// doi.org/10.1016/j.supflu.2013.11.008.

[26] Silva LN, Cardoso CC, Pasa VMD. Synthesis and characterization of esters from different alcohols using Macauba almond oil to substitute diesel oil and jet fuel. Fuel 2016;166:453-60. https://doi.org/10.1016/j.fuel.2015.10.070.

[27] Souza GK, Scheufele FB, Pasa TLB, Arroyo PA, Pereira NC. Synthesis of ethyl esters from crude macauba oil (Acrocomia aculeata) for biodiesel production. Fuel 2016;165:360-6. https://doi.org/10.1016/j.fuel.2015.10.068.

[28] Iha OK, Alves FCSC, Suarez PAZ, de Oliveira MBF, Meneghetti SMP, Santos BPT, et al. Physicochemical properties of Syagrus coronata and Acrocomia aculeata oils for biofuel production. Ind Crops Prod 2014;62:318-22. https://doi.org/10.1016/j. indcrop.2014.09.003.

[29] Michelin S, Penha FM, Sychoski MM, Scherer RP, Treichel H, Valério A, et al. Kinetics of ultrasound-assisted enzymatic biodiesel production from Macauba coconut oil. Renew Energy 2015;76:388-93. https://doi.org/10.1016/j.renene.2014 11.067.

[30] Lima A de, Silva AM de O e, Trindade RA, Torres RP, Mancini-Filho J. Composição química e compostos bioativos presentes na polpa e na amêndoa do pequi (Caryocar brasiliense, Camb.). Rev Bras Frutic 2007;29:695-8. doi:10.1590/S010029452007000300052.

[31] Guedes AMM, Antoniassi R, Galdeano MC, Grimaldi R, de Carvalho MG, Wilhelm $\mathrm{AE}$, et al. Length-scale specific crystalline structural changes induced by molecular randomization of pequi oil. J Oleo Sci 2017;66:469-78. https://doi.org/10.5650/ jos.ess16192.

[32] Coimbra MC, Jorge N. Characterization of the Pulp and Kernel Oils from Syagrus oleracea, Syagrus romanzoffiana, and Acrocomia aculeata. J Food Sci 2011;76:C1156-61. https://doi.org/10.1111/j.1750-3841.2011.02358.x.

[33] de Mariano RG de B, Couri S, Freitas SP. Enzymatic technology to improve oil extraction from Caryocar brasiliense camb. (Pequi) Pulp. Rev Bras Frutic 2009;31:637-43. https://doi.org/10.1590/s0100-29452009000300003.

[34] Ribeiro MC, Vilas Boas EV de B, Riul TR, Pantoja L, Marinho HA, dos Santos AS. Influence of the extraction method and storage time on the physicochemical properties and carotenoid levels of pequi (Caryocar brasiliense Camb.) oil. Food Sci Technol 2012;32:386-92. https://doi.org/10.1590/s0101-20612012005000053.

[35] Schuchardt U, Sercheli R, Matheus R. Transesterification of vegetable oils: a review general aspects of transesterification transesterification of vegetable oils acid-catalyzed processes base-catalyzed processes. J Braz Chem Soc 1998;9:199-210. https://doi.org/10.1590/S0103-50531998000300002.

[36] ABNT - Associação brasileira de normas técnicas. NBR 10441. Determinação da viscosidade cinemática e cálculo da viscosidade dinâmica; 1998.

[37] ABNT - Associação brasileira de normas técnicas. NBR 14358. Cálculo do indice de viscosidade a partir da viscosidade cinemática; 2005.

[38] ABNT - Associação brasileira de normas técnicas. NBR 15764. Determinação do teor total de ésteres por cromatografia gasosa; 2015

[39] European Standard - EN 15751. Automotive Fuels. Fatty acid methyl ester (FAME) fuel and blends with diesel fuel. Determination of oxidation stability by accelerated oxidation method; 2014.

[40] Javidialesaadi A, Raeissi S. Biodiesel production from high free fatty acid-content oils: experimental investigation of the pretreatment step. APCBEE Proc 2013;5:474-8. https://doi.org/10.1016/j.apcbee.2013.05.080.

[41] Farobie O, Matsumura Y. State of the art of biodiesel production under supercritical conditions. Prog Energy Combust Sci 2017;63:173-203. https://doi.org/10.1016/j. pecs.2017.08.001.

[42] Ferrari R, Oliveira V. Scabio a. Biodiesel from soybean: characterization and 
consumption in an energy generator. Quim Nova 2005;28:19-23. https://doi.org/ $10.1590 /$ S0100-40422005000100004.

[43] Fernandes DM, Serqueira DS, Portela FM, Assunção RMN, Munoz RAA, Terrones MGH. Preparation and characterization of methylic and ethylic biodiesel from cottonseed oil and effect of tert-butylhydroquinone on its oxidative stability. Fuel 2012;97:658-61. https://doi.org/10.1016/j.fuel.2012.01.067.

[44] dos Santos AF, da Silva MV, Kwiatkowski A, Clemente E, de Araújo JHB. Physicalchemical evaluation of pequi pulp crude oil. Rev Bras Pesqui Em Aliment 2010;1:111. https://doi.org/10.14685/rebrapa.v1i2.25.

[45] Barbosa EA, Antunes R, Farias TM, Lopes PSN. Análise da Qualidade do Óleo de Pequi Produzido e Comercializado no Município de Januário-MG. Brasil Rev Bras Agroecol 2009;4:3314-8.

[46] ANP - Agência Nacional do Petróleo, Gás Natural e Biocombustíveis. Resolução N. $45 ; 2014$.

[47] Borges KA, Batista ACF, de Souza Rodrigues H, Hernandes Terrones M, Tironi Vieira A, Firmino de Oliveira M. Production of methyl and ethyl biodiesel fuel from pequi oil (Caryocar brasiliensis Camb.). Chem Technol Fuels Oils 2012;48:83-9. https:// doi.org/10.1007/s10553-012-0342-3.

[48] Folayan AJ, Anawe PAL, Aladejare AE, Ayeni AO. Experimental investigation of the effect of fatty acids configuration, chain length, branching and degree of unsaturation on biodiesel fuel properties obtained from lauric oils, high-oleic and high-linoleic vegetable oil biomass. Energy Rep 2019;5:793-806. https://doi.org/ 10.1016/j.egyr.2019.06.013.

[49] Pradelle F, Leal Braga S, Fonseca de Aguiar Martins AR, Turkovics F, Nohra Chaar Pradelle R. Experimental assessment of some key physicochemical properties of diesel-biodiesel-ethanol (DBE) blends for use in compression ignition engines. Fuel 2019;248:241-53. https://doi.org/10.1016/j.fuel.2019.03.087.

[50] Melero JA, Vicente G, Morales G, Paniagua M, Bustamante J. Oxygenated compounds derived from glycerol for biodiesel formulation: influence on EN 14214 quality parameters. Fuel 2010;89:2011-8. https://doi.org/10.1016/j.fuel.2010.03. 042.

[51] Pinheiro I, Luis S, Ferreira C. Revisão:Biodiesel- Parametros de Qualidade e Metodos Analiticos. QuimNova 2009;32:1596-608.

[52] Marques Cardoso CM, Zavarize DG, Gama Vieira GE. Transesterification of Pequi (Caryocar brasiliensis Camb.) bio-oil via heterogeneous acid catalysis: catalyst preparation, process optimization and kinetics. Ind Crops Prod 2019;139:111485https://doi.org/10.1016/j.indcrop.2019.111485.

[53] Rosset IG, Tavares MCH, Assaf EM, Porto ALM. Catalytic ethanolysis of soybean oil with immobilized lipase from Candida antarctica and 1H NMR and GC quantification of the ethyl esters (biodiesel) produced. Appl Catal A Gen 2011;392:136-42. https://doi.org/10.1016/j.apcata.2010.10.035.

[54] Thoai DN, Photaworn S, Kumar A, Prasertsit K, Tongurai C. A novel chemical method for determining ester content in biodiesel. Energy Proc 2017;138:536-43. https://doi.org/10.1016/j.egypro.2017.10.156.

[55] da César A da S, Almeida Fde A, de Souza RP, Silva GC, Atabani AE. The prospects of using Acrocomia aculeata (macaúba) a non-edible biodiesel feedstock in Brazil. Renew Sustain Energy Rev 2015;49:1213-20. https://doi.org/10.1016/j.rser.2015.
04.125.

[56] Oliveira FCC, Brandão CRR, Ramalho HF, da Costa LAF, Suarez PAZ, Rubim JC. Adulteration of diesel/biodiesel blends by vegetable oil as determined by Fourier transform (FT) near infrared spectrometry and FT-Raman spectroscopy. Anal Chim Acta 2007;587:194-9. https://doi.org/10.1016/j.aca.2007.01.045.

[57] Sahoo S, Chakraborti C, Behera P, Mishra S. FTIR and raman spectroscopic investigations of a Norfloxacin/Carbopol934 polymeric suspension. J Young Pharm 2012;4:1-8. https://doi.org/10.4103/0975-1483.100017.

[58] Bhardwaj RM. Control and prediction of solid-state of pharmaceuticals Cham: Springer International Publishing; 2016. https://doi.org/10.1007/978-3-31927555-0.

[59] Bezerra TMGA, Rodrigues FEA, Arruda DTD, Ricardo NMPS, Dantas MB, de Araújo KC. Chromatography, spectroscopy and thermal analysis of oil and biodiesel of sesame (Sesamum indicum) - an alternative for the Brazilian Northeast. Ind Crops Prod 2016;91:264-71. https://doi.org/10.1016/j.indcrop.2016.07.029.

[60] Raslavičius L, Striūgas N, Felneris M, Skvorčinskienė R, Miknius L. Thermal characterization of P. moriformis oil and biodiesel. Fuel 2018;220:140-50. https://doi. org/10.1016/j.fuel.2018.02.010.

[61] Tutunea D. Thermal investigation of biodiesel blends derived from rapeseed oil. J Therm Anal Calorim 2013;111:869-75. https://doi.org/10.1007/s10973-0122213-x.

[62] Vega-Lizama T, Díaz-Ballote L, Hernández-Mézquita E, May-Crespo F, CastroBorges P, Castillo-Atoche A, et al. Thermogravimetric analysis as a rapid and simple method to determine the degradation degree of soy biodiesel. Fuel 2015;156:158-62. https://doi.org/10.1016/j.fuel.2015.04.047.

[63] Mothé CG, De Castro BCS, Mothé MG. Characterization by TG/DTG/DSC and FTIR of frying and fish oil residues to obtain biodiesel. J Therm Anal Calorim 2011;106:811-7. https://doi.org/10.1007/s10973-011-1795-z.

[64] Balabin RM, Smirnov SV. Variable selection in near-infrared spectroscopy: benchmarking of feature selection methods on biodiesel data. Anal Chim Acta 2011;692:63-72. https://doi.org/10.1016/j.aca.2011.03.006.

[65] Zhou J, Xiong Y, Gong Y, Liu X. Analysis of the oxidative degradation of biodiesel blends using FTIR, UV-Vis, TGA and TD-DES methods. Fuel 2017;202:23-8. https://doi.org/10.1016/j.fuel.2017.04.032.

[66] Li H, Niu S, Lu C, Wang Y. Comprehensive investigation of the thermal degradation characteristics of biodiesel and its feedstock oil through TGA-FTIR. Energy Fuels 2015;29:5145-53. https://doi.org/10.1021/acs.energyfuels.5b01054.

[67] Soares IP, Rezende TF, Silva RC, Castro EVR, Fortes ICP. Multivariate calibration by variable selection for blends of raw soybean oil/biodiesel from different sources using Fourier transform infrared spectroscopy (FTIR) spectra data. Energy Fuels 2008;22:2079-83. https://doi.org/10.1021/ef700531n.

[68] Niu S, Zhou Y, Yu H, Lu C, Han K. Investigation on thermal degradation properties of oleic acid and its methyl and ethyl esters through TG-FTIR. Energy Convers Manage 2017;149:495-504. https://doi.org/10.1016/j.enconman.2017.07.053.

[69] Zhang F, Adachi D, Tamalampudi S, Kondo A, Tominaga K. Real-time monitoring of the transesterification of soybean oil and methanol by fourier-transform infrared spectroscopy. Energy Fuels 2013;27:5957-61. https://doi.org/10.1021/ef4012998. 